Check for updates

Cite this as: $B M J 2020 ; 370: \mathrm{m} 3693$ http://dx.doi.org/10.1136/bmj.m3693 Published: 22 September 2020

\section{Uruguay is winning against covid-19. This is how}

This Feature by Luke Taylor (BMJ 2020;370:m3575, doi:) was first published with several mistakes. It stated that "Uruguay has recorded 1527 infections and 142 deaths [should be 42 deaths] at the time of writing, despite beginning to reopen some schools in March [should be April] and never enforcing lockdowns [specifically, no mandatory stay-at-home orders]." It also stated: "Uruguay's first case of covid-19 was confirmed in the capital of Montevideo on 13 May [should be 13 March].” The article has now been corrected. 